\title{
Variation in caries treatment proposals among dentists in Norway; the best interest of the child
}

\author{
A. Rønneberg ${ }^{1 *}$, A. B. Skaare ${ }^{1}$, B. Hofmann ${ }^{2,3}$, I. Espelid $^{1}$
}

${ }^{1}$ Dept. of Paediatric Dentistry and Behavioural Science, Institute of Clinical Dentistry, Faculty of Dentistry, University of Oslo, Norway

${ }^{2}$ Section for Health, Technology and Society, The Norwegian University of Science and Technology (NTNU), Gjøvik, Norway

${ }^{3}$ Centre for Medical Ethics, University of Oslo, Norway

*Corresponding author: Anne Rønneberg, anne.ronneberg@ odont.uio.no

Eur Arch Paediatr Dent. 2017 Oct;18(5):345-353. doi: 10.1007/s40368-017-0298-4. Epub 2017 Jul 26.

\section{Acknowledgments}

The authors would like to thank dentists in the Public Dental Service in the counties of Finnmark, Nordland, Sør-Trøndelag, Møre og Romsdal, Hordaland, Vest-Agder, Hedmark and Oslo for their contributions to the study.

\section{Compliance with Ethical Standards}

All authors declares that they have no conflict of interest.

This article does not contain any studies with human participants performed by any of the authors. 


\section{Introduction}

Caries continues to be a burden for children at high caries risk (Arora et al. 2011). In patients with caries restorative therapy is often indicated. In many countries, the reimbursement system is a barrier for treatment decisions (Slayton 2015). In Scandinavia, the public dental health care system offers free and regular oral health care for children and adolescents, so there are no economic barriers for patients. Other barriers may exist, such as demands for efficiency and lack of resources in the Public Dental Service (PDS), little experience with sedation and behaviour management procedures among clinicians, etc. Although treatment concepts have changed considerably towards non-operative treatment of enamel lesions in Norway (Vidnes-Kopperud et al. 2011), there is still need for operative dentistry, particularly for severe lesions. In Sweden in 2002, a consensus conference concluded that progression of the carious lesion to an advanced stage could result in local and general infections, increased risk of pain, space loss and malocclusion and an increased risk of caries in the first permanent molar (Hugoson et al. 2001). Based on this, the conclusion was that active carious lesions should be treated without delay, and as a basic rule all advanced carious lesions ought to be restored. Little is known about the variation in treatment decisions among dentists dealing with severe caries in preschool children. Operative treatment in preschool children may be stressful for the dentist, a factor that may influence the dentist's attitude towards treating preschool children (Ronneberg et al. 2015). Thus, supervised neglect may occur (nontreatment of severe caries) notwithstanding that this puts the child at risk of pain and suffering (Duggal 2006).

According to the United Nations Convention on the Rights of the Child, children have the right to the best health care possible. When discussing the best interest of the preschool child with respect to treatment of severe caries, biomedical ethical principles like non-maleficence, beneficence, and justice are crucial. Non-maleficence means "no-harm" or to avoid inflicting harm. Beneficence is about the balancing of benefits of treatment against the risks. Justice concerns the distribution of health resources and deciding who gets what treatment (fairness and equality). The principle of autonomy, i.e., self-determination, is safeguarded by guardians in small children, normally by their parents (Federation 2007; Rossel et al. 2013).

This study aimed to explore the variation in choices of treatment-related-decisions among dentists in the Norwegian PDS who treat severe caries in preschool children. The dentists were presented with two scenarios for five-year-old children with severe caries in primary 2 
teeth, with and without symptoms, respectively. We sought to evaluate the replies in relation to what is in the best interest of the child and the child's rights to the highest standard of health care.

\section{Material and Methods}

Sample

All dentists working in the Public Dental Service (PDS) in eight counties in Norway received an electronically questionnaire, (an internet-based software, QuestBack Norway, Oslo) in February 2013. The questionnaire, named " $A$ " in the following text, was pre-coded and responses were anonymous. The selected eight counties were considered representative for the Norwegian population with respect to demographics and number of dentists. A power analysis was undertaken to calculate the number of participants needed. A test power of $80 \%$ was chosen to detect a $10 \%$ difference in the distribution of replies between male and female dentists. This required at least 402 participants in the study. A dropout of up to $35 \%$ was estimated based on previous experience. The respective Chief Dental Officers provided a total of 611 e-mail addresses for all employed dentists. Inclusion criteria were dentists treating patients between 2 and 18 years at least once a week. The study was approved by the Norwegian Social Science Data Services. Two reminders were sent automatically by the software to non-responders, two weeks apart. The age and gender distributions of respondents were checked against Statistics Norway's dental register of dentists employed in the PDS. A pilot study was preformed before the main study and comments were taken into account.

The questionnaires

Questionnaire A consisted of 32 questions and two hypothetical case scenarios. In the present paper seven variables from the questionnaire were included in addition to the two case scenarios (Tables $1 \& 2$ ). In two recent papers other variables from questionnaire A were presented (Ronneberg et al. 2015; Strom et al. 2015).

A second precoded electronic questionnaire (questionnaire B), using the same software (QuestBack), was sent to all working specialists and postgraduate students in paediatric dentistry in Norway ( $n=37)$. Questionnaire B included only the two hypothetical case scenarios from questionnaire A. To ensure anonymity of this small group of specialized 
dentists, no background questions were asked. This group of paediatric dentists is referred to as PDs, and the general dental practitioners as GDPs, in this paper.

The PDs were instructed to characterize the different treatment options as being either "Best practice", "Acceptable" or "Non-acceptable", dichotomised into "Appropriate practice (A)" (including "Best practice", "Acceptable") and "Non-appropriate practice (N-A)" (Fig. 3). The majority opinion of the PDs was used for validation purpose of the replies by the GDPs. The case scenarios were designed to reflect common dental conditions related to severe caries among five-year-old children. The two case scenarios and treatment options are presented in Table 2.

\section{Statistical analysis}

Data were analysed using SPSS version 20.0 (Statistical Package for the Social Sciences; SPSS Inc., Chicago, Ill., USA). The dentists' practice profile, sociodemographic background, treatment options and pre-coded response choices were dichotomized (Table 1). Cross tables were made and Chi-square statistics was applied. The level of statistical significance was set to $5 \%$.

\section{Results}

Of the 611 general dental practitioners who received the questionnaire, 12 declined to participate and one was excluded due to an incomplete returned form. Of the remaining 598 GDPs, $391(65 \%)$ responded. A majority were females $(n=270,70 \%)$. Three dentists did not report their gender.

There were no statistically significant differences between the respondents and all GDPs in Norway with respect to age $(p=0.31)$ and gender distribution $(p=0.43)$. The majority of the respondents $(n=314,81 \%)$ had been educated in the Nordic countries; $19 \%(n=75)$ had studied abroad. Some of the included respondents did not answer all questions.

Of the 37 paediatric dentists who were requested to participate, 29 (78\%) completed the survey.

In Case scenario 1 (Table 1, Fig.1, Fig. 3), presenting a five-year old child with the fairly common condition of pulpitis and pain due to deep caries, neither the GDPs or the PDs supported the alternative of wait and recall in about $3-6$ months or doing acute treatment and 
restraining the child if necessary. A majority of the GDPs preferred a new appointment with behaviour management techniques (BMT). This choice was also found appropriate by the PDs although all the PDs preferred treatment with conscious sedation. Half of the GDPs selected this option. Prescribing antibiotics was not appropriate, according to the GDPs, who were supported by the PDs. Few GDPs, opted for referral for treatment under general analgesia, which was mainly chosen as an option by the PDs (Fig. 3). There were no statistically significant differences between answers by male and female dentists. Of the dentists educated within the Nordic countries, more than half chose to treat a child with caries and pain (Case 1, Fig.1) under conscious sedation, compared with approximately one third of the non-Nordic educated dentists $(p=0.003)$. Approximately $10 \%$ of the Nordic-educated GDPs would treat immediately and restraining the child if necessary, whereas $20 \%$ of the non-Nordic educated opted for this alternative $(\mathrm{p}=0.011$; Table 3$)$.

Dentists with more than 10 years of clinical experience, proposed to do less conscious sedation $(p=0.029)$, less BMT ( $p=0.006)$ but more referrals for dental treatment under general analgesia $(p=0.048)$. Dentists' self-reported clinical treatment time with children aged 2 - 18 years, dentists' use of local analgesia and their self-perception of doing restorative treatment were not associated with their choice of treatment option.

Dentists undertaking sedation frequently preferred more often to make a new appointment for sedation $(p=0.001)$. Those who rarely used sedation often selected the option to make a new appointment in $3-6$ months $(p=0.007)$ (Table 3).

In Case scenario 2 (Table 2, Fig. 2, Table 4), a five-year-old boy with caries without symptoms, $81 \%$ of the GDPs claimed that the virtual dentist had taken a wrong decision by waiting 9 months to see him again. This view was supported by all PDs.

Of the dentists with more than 10 years of clinical practice, about $1 / 4$ of the respondents supported the dentist's decision to postpone treatment for nine months which was significantly more than the support of their younger colleagues $(p=0.002)$. The same pattern was disclosed when looking at clinical treatment time with children and adolescents. Of those spending $60 \%$ or more working time with this patient group, about $1 / 4$ agreed to postpone the treatment, which was more than among those working less with young children $(p=0.004)$ (Table 4). 
Among dentists who rarely used conscious sedation, $22 \%$ agreed to postpone the treatment. This is in contrast with those who frequently used sedation, of whom only $3 \%$ agreed with the dentist in the case scenario $2(p=0.028)$.

\section{Discussion}

Dentists working in PDS in Norway had different approaches to the best treatment of fiveyear old children with severe caries. Country of education, years of practice and treatment time working with children was associated with their decision making regarding treatment. The validation of the various treatment options by PDs showed that they mostly agreed with GDPs choices although there were some disparities.

Two common clinical situations showing five-year-old children with severe caries in primary teeth (Tables $1 \& 2$ and Figs. $1 \& 2$ ) were presented to general practitioners (GDPs) employed in the Public Dental Service (PDS) in Norway and PDs as well as specializing dentists. The response rate for GDPs (65\%) was comparable with that in other surveys (Tickle et al. 2007; Hill et al. 2008; Shelley et al. 2012; Brahm et al. 2013; Lee et al. 2013). The respondents accounted for about one-third of all public dental officers in Norway. As there was no statistically significant difference between the study sample and all PDS dentists in Norway with respect to age and sex distribution, the sample was considered representative.

A weakness of the study is that the responses to the two case scenarios do not necessarily reflect dentists' actual clinical activity. Bitewings and clinical photos show teeth with caries with different severity, which may have confused some dentists. Nevertheless, the survey expose dentists for everyday issues which they handle quite often. Only two case scenarios were selected to avoid overburdening of the respondents. In general, it might be difficult to attain a very high response rate for electronic surveys among dentists. In the planning of our study we addressed the ten recommendations for surveys made by Shelly et al, (Shelley et al. 2012).

To validate the treatment options in the light of the UN Convention of the Rights of the Child, article 3; (Child 2016) in the best interest of the child, specialists in paediatric dentistry (PDs) and dentists under specialization in paediatric dentistry, were asked to select their preferences with respect to treating the two cases. A response rate of $78 \%$ in the PD group was 
considered good. It is known from other studies that also in a group of specialists there will be variation in the views, but using a majority based answer makes it possible to judge and validate the preferences made by the GDPs. An important premise for interpreting the results is that all dental treatment of children (except for orthodontics) is free of charge in Norway. There is thus no direct economic incentive for choosing a particular treatment option. One might expect that this would have an impact when focusing on the ethical principle of justice were persons have the same right of access to dental care and similar cases should be treated similarly. Nevertheless, the results demonstrate that it is difficult to establish a common understanding of what treatment is in the best interest of the child, even among paediatric dentists. Randomised clinical trials are rare in paediatric dentistry and this hampers evidencebased discussions about the best way to treat children (Tickle et al. 2007). The present findings of different approach patterns for pre-school children with dental caries are consistent with similar studies among GDPs and PDs in UK and Hong Kong (Duggal 2006; Lee et al. 2013).

Nearly $70 \%$ of the respondents were women, which reflects the gender distribution of the dentists employed in the PDS. The results did not show any gender related differences regarding the treatment preferences. However, other studies have demonstrated that operators' gender may have effects on how patients are treated (Atchison et al. 2002; Grytten et al. 2002; Zitzmann et al. 2011). The wait and see approach or holding the child when undertaking acute treatment, was not favoured by the GDPs nor by the PDs.

Using restraint in the dental setting has been broadly discussed among dentists treating children. Some European countries, including Norway, have laws against the use of physical restraint, and therefore it was surprising that some of the dentists would use or accept restraint of the child (Fig. 3). Of the GDPs, who opted for holding the child, there was a statistically significant difference between those educated within and without the Nordic region. This may be due to different educational, cultural and social backgrounds, but using restraints can infringe the principles of beneficence and non-maleficence (do not harm) in biomedical ethics. This is due to long term psychological impact and the principle of autonomy, if the mother's self-interest in giving proxy consent over-rides the best interests of the child (Buchanan, Brock 1990). The child's experiences from the forced dental treatment situation 
may affect future dental visits, causing anxiety and behaviour management problems (BMP) (Klingberg, Broberg 2007;Curzon 2008).

Pre-school children are not fully autonomous persons. Nevertheless, they have to be informed and their assent is important for the process and the outcome. Their lack of autonomy is compensated for by the parent(s) as guardian(s). In cases where the parents' choice for the children conflicts with what professionals or ordinary persons would consider to be in the best interest of the child, one could argue that others than the parents would be a more appropriate guardian, e.g., the dentist. Moreover, if the parents demand handling of the child which goes against the professional's judgement, there will be a conflict between professional autonomy and standard, and the proxy autonomy of the child. Dental treatment situations seldom need immediate interventions and can often be postponed. Caries lesions are not life-threatening conditions and once the acute pain is relieved, efforts to provide positive long-term care for the child should be given priority.

In scenario 1, a new appointment using Behaviour Management Techniques (BMT) was the preferred approach for most of the GDPs, and appropriate practice according to PDs (Fig. 3). The younger dentists would use BMT more frequently than their older colleagues. Some dentists may think they have to do immediate operative treatment and forget to think of a holistic and long-term approach to the minor child. Tickle et al. discussed different treatment options from the child's perspective (Tickle et al. 2007). In some cases the ART technique may be considered. The method is based on caries excavation using hand instruments only and partial removal of caries. The method may be a reasonable choice when conventional therapy is difficult. Longevity of single surface ART restorations is comparable to conventional restorations (Hilgert et al. 2016). Young children show fear of more and different stimuli than older children (Klingberg, Broberg 2007; Krekmanova et al. 2009). Behaviour management is one of the corner stones in paediatric dentistry and any approach to the dental child patient must be rooted in empathy and concern for the well-being of the child (Roberts et al. 2010).

It is important to improve the child's oral health, but keeping the child's perspective and interests in mind. The curriculum for undergraduate students within the Nordic countries has in recent years focused on different dental treatment techniques to prevent BMP and dental anxiety. This association was shown in a recent study (Strom et al. 2015). Communication, 
empathic skills and ethical considerations have increasingly been emphasized (Roberts et al. 2010). This might explain why younger dentists favoured BMT as one of the best approaches to children with pain and caries, supported by nearly all of the PDs. BMT and active use of painkillers may be good practice for many children, but sometimes operative treatment is necessary and the use of conscious sedation may be preferable.

Half of the GDPs suggested giving a new appointment for conscious sedation in Case scenario 1 and this was supported by the PDs (Fig. 3). The Nordic educated dentists and those with less than 10 years of work experience preferred conscious sedation. Different treatment approaches have evolved over time and this is also reflected in dental education. Challenges to pain management in children have enjoyed increased attention (Krauss et al. 2016), and oral conscious sedation is a necessary part of paediatric analgesia (Rosenbaum et al. 2009). In a previous paper, we revealed that only about $30 \%$ of dentists who found it difficult to do restorative treatment in young children used conscious sedation (Ronneberg et al. 2015). Tickle et al. (Tickle et al. 2007) also reported that both GDPs and PDs used low level sedation. These findings and the previously discussed ethical considerations support the importance of guidelines and continuing training programs regarding conscious sedation to provide optimal dental care for preschoolers.

Untreated, severe caries can have implication not just for dental health, but may also have sequelae for general health and quality of life (Wong et al. 2011). The use of antibiotics, in an attempt to relieve the symptoms in the case with pulpitis, was chosen by very few of the GDPs (Fig. 3). The overall benefits of prescribing antibiotics are limited by a number of sideeffects, and the development of resistant strains of microbes is a cause for worldwide concern. It is accepted that they should only be used when there is evidence for spreading infections and for prevention of metastatic infections like endocarditis (Dailey, Martin 2001; Palmer et al. 2001). As a routine treatment, antibiotics should not be prescribed for localized infections like pulpitis. However, in a study from Britain, it was demonstrated that three-quarters of the patients had received antibiotics for pulpitis without symptoms of a possible spreading infection (Dailey, Martin 2001). These results also suggest a need for the implementation of guidelines (Palmer et al. 2001).

Only a few GDPs would refer children for dental treatment under general analgesia (GA), which was judged appropriate by the PDs (Fig. 3). The low portion of GDPs preferring GA, 
may, among other things, be due to the long waiting time. Lack of capacity may be a barrier to treatment under GA. For a child in pain, GA should ideally be carried out within a short time. Dental treatment under GA is expensive and consequently limits the extent to which such service is available. Wilson et al. discuss that GA has gained popularity in the comprehensive restorative dental care for children (Wilson, Alcaino 2011).

In Case scenario 2 (Table 2), $80 \%$ of the GDPs claimed that the dentist had taken a wrong decision by waiting nine months to see the boy again, which was in accordance with the PD's assessment. The child did not have pain, but had severe caries. Dentists who had worked more than 10 years, mainly working with children and adolescents and using conscious sedation rarely, supported the waiting approach. Dentists may feel, whether intended or not, that caries may become arrested. It is therefore possible that the dentists judged that the caries shown in Case scenario 2 (Fig 2), was or would become chronic. This was a common understanding among the authors, but this was not verified clinically. From the child's perspective and the parental wishes, the choice of doing nothing may be a right decision as long as there is no pain, pulpitis or abscesses, but in the long run preventing further caries development by regular recall and sufficient home care is of great importance. Again, the variation of answers indicates differences in opinion and uncertainty among GDPs regarding the treatment of children with primary dentition caries. Tickle et al. and Lee et al. have earlier described the same pattern (Tickle et al. 2007; Lee et al. 2013). Lack of guidelines and clinical evidence entail questions like the one raised at the consensus conference on caries in the primary dentition in Sweden; "What are the consequences of not treating caries in the primary dentition?" (Espelid et al. 2013). The consensus report concluded that it is a common understanding among university teachers in paediatric dentistry that it is important to keep children caries free if possible and treat caries when it occurs. Further they concluded from an ethical point of view that all children have a right to optimal prevention and care of dental caries, which is according to the Rights of the Child.

\section{Conclusions}

GDPs expressed different approaches on how to handle severe caries in five-year-old children and choice of treatment was associated with region of education and experience as a dentist. GDPs educated abroad the Nordic countries used more restraint and less conscious sedation 
and dentists with work experience less than ten years used more BMT and sedation. The PDs favored both BMT, the use of sedation and referral for GA.

Awareness of ethical principles, such as the principle of beneficence balancing the harms and the benefits for the best interest of the child, is crucial. Further, the principle of nonmaleficence (not doing harm) and justice (distribution, fairness, equity), but also respect for autonomy, are important, as are children's rights to good and effective dental health care.

Awareness of ethical principles when having the child's best interest in mind can assist clinicians in everyday clinical practice. Clinical guidelines based on such ethical principles should be implemented in paediatric dentistry. However, guidelines are not imperatives. They can be waived, when there are good and explicit reasons for doing so.

Keywords: children; dental anxiety; dentist-patient relations; ethics; clinical; behavioural management

Authors' contributions

Study concept, design and methodology - AR, ABS, BH, IE. Data collection and data entry AR. Supervision - IE, ABS. Analysis and interpretation of data - AR, ABS, IE. Writing, review, critique, comments and revision of manuscript - AR, ABS, BH, IE. All authors have read and approved the manuscript.

Compliance with Ethical Standards

All authors declare that they have no conflict of interest.

This article does not contain any studies with human participants performed by any of the authors. 


\section{References}

Arora A, Schwarz E, Blinkhorn AS. Risk factors for early childhood caries in disadvantaged populations. Journal of investigative and clinical dentistry. 2011;2(4):223-8. doi:10.1111/j.2041-1626.2011.00070.x.

Atchison KA, Bibb CA, Lefever KH et al. Gender differences in career and practice patterns of PGD-trained dentists. J Dent Educ. 2002;66(12):1358-67.

Brahm CO, Lundgren J, Carlsson SG et al. Dentists' skills with fearful patients: education and treatment. Eur J Oral Sci. 2013;121(3 Pt 2):283-91.

Buchanan AE, Brock DW. Deciding for Others The Ethics of Surrogate Decision making. Cambridge, United Kingdom: Cambridge University Press; 1990.

UN Convention on the Rights og the Child [database on the Internet]. United nations human rights office of the high commissioner. 2016. Available from: http://www.ohchr.org/en/professionalinterest/pages/crc.aspx. Accessed: June 2016

Curzon M. Behavioural management in paediatric dentistry: historical perspectives. Eur Arch Paediatr Dent. 2008;9 Suppl 1:3-5.

Dailey YM, Martin MV. Are antibiotics being used appropriately for emergency dental treatment? Br Dent J. 2001;191(7):391-3. doi:10.1038/sj.bdj.4801190a.

Duggal M. Providing children with the quality dental care they deserve. Community Dent Health. 2006;23(2):66-8.

Espelid I, Alanen P, Hofmann B. Evidence based dentistry and ethics. Nor Tannlegeforen Tid. 2013;123:28-32.

Federation FWD. FDI World Dental Federation. Dental ethics manual. France: FDI World Dental Federation, 2007. . http://www.fdiworldental.org/media/70462/1fdi_dental_ethics_manual_1st_edition_2007.pdf. 2007.

Grytten J, Skau I, Holst D. Hvor skjevfordelte er tannlegene i Norge? Nor Tannlegefor Tidende. 2002;112:172-7. 
Hilgert LA, Frencken JE, de Amorim RG et al. A study on the survival of primary molars with intact and with defective restorations. International journal of paediatric dentistry. 2016;26(5):383-90. doi:10.1111/ipd.12215.

Hill KB, Hainsworth JM, Burke FJ et al. Evaluation of dentists' perceived needs regarding treatment of the anxious patient. Br Dent J. 2008;204(8):E13; discussion 442-3. doi:10.1038/sj.bdj.2008.318.

Hugoson A, Falk M, Johansson S. Consensus Conference on Caries in the Primary Dentition and its Clinical Management. Jönköping, Sweden: Gothia; 2001.

Klingberg G, Broberg AG. Dental fear/anxiety and dental behaviour management problems in children and adolescents: a review of prevalence and concomitant psychological factors. International journal of paediatric dentistry. 2007;17(6):391-406. doi:10.1111/j.1365263X.2007.00872.x.

Krauss BS, Calligaris L, Green SM et al. Current concepts in management of pain in children in the emergency department. Lancet (London, England). 2016;387(10013):83-92. doi:10.1016/s0140-6736(14)61686-X.

Krekmanova L, Bergius M, Robertson A et al. Everyday- and dental-pain experiences in healthy Swedish 8-19 year olds: an epidemiological study. International journal of paediatric dentistry. 2009;19(6):438-47. doi:10.1111/j.1365-263X.2009.01016.x.

Lee GH, McGrath C, Yiu CK. The care of the primary dentition by general dental practitioners and paediatric dentists. Int Dent J. 2013;63(5):273-80. doi:10.1111/idj.12055.

Palmer NO, Martin MV, Pealing R et al. Paediatric antibiotic prescribing by general dental practitioners in England. International journal of paediatric dentistry. 2001;11(4):242-8.

Roberts JF, Curzon ME, Koch G et al. Review: behaviour management techniques in paediatric dentistry. Eur Arch Paediatr Dent. 2010;11(4):166-74.

Ronneberg A, Strom K, Skaare AB et al. Dentists' self-perceived stress and difficulties when performing restorative treatment in children. Eur Arch Paediatr Dent. 2015;16(4):341-7. doi:10.1007/s40368-014-0168-2. 
Rosenbaum A, Kain ZN, Larsson P et al. The place of premedication in pediatric practice. Paediatric anaesthesia. 2009;19(9):817-28. doi:10.1111/j.1460-9592.2009.03114.x.

Rossel JH, Lathi S, Strand GV. Ethics in dental education from a Nordic perspective. Nor Tannlegeforen Tid 2013;123:34-9.

Shelley AM, Brunton P, Horner K. Questionnaire surveys of dentists on radiology. Dento maxillo facial radiology. 2012;41(4):267-75. doi:10.1259/dmfr/58627082.

Slayton RL. Clinical Decision-making for Caries Management in Children: An Update. Pediatric dentistry. 2015;37(2):106-10.

Strom K, Ronneberg A, Skaare AB et al. Dentists' use of behavioural management techniques and their attitudes towards treating paediatric patients with dental anxiety. Eur Arch Paediatr Dent. 2015;16(4):349-55. doi:10.1007/s40368-014-0169-1.

Tickle M, Threlfall AG, Pilkington L et al. Approaches taken to the treatment of young children with carious primary teeth: a national cross-sectional survey of general dental practitioners and paediatric specialists in England. Br Dent J. 2007;203(2):E4; discussion 102-3. doi:10.1038/bdj.2007.570.

Vidnes-Kopperud S, Tveit AB, Espelid I. Changes in the treatment concept for approximal caries from 1983 to 2009 in Norway. Caries research. 2011;45(2):113-20. doi:10.1159/000324810.

Wilson S, Alcaino EA. Survey on sedation in paediatric dentistry: a global perspective. International journal of paediatric dentistry. 2011;21(5):321-32. doi:10.1111/j.1365263X.2011.01127.x.

Wong HM, McGrath CP, King NM et al. Oral health-related quality of life in Hong Kong preschool children. Caries research. 2011;45(4):370-6. doi:10.1159/000330231.

Zitzmann NU, Zemp E, Weiger R et al. Does a clinician's sex influence treatment decisions? Int J Prosthodont. 2011;24(6):507-14. 


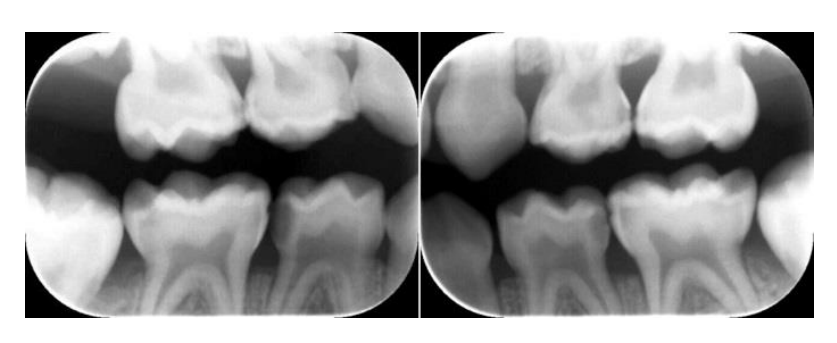

Fig. 1 Case scenario 1. Bite-wings of a five-year-old girl with pain due to severe caries

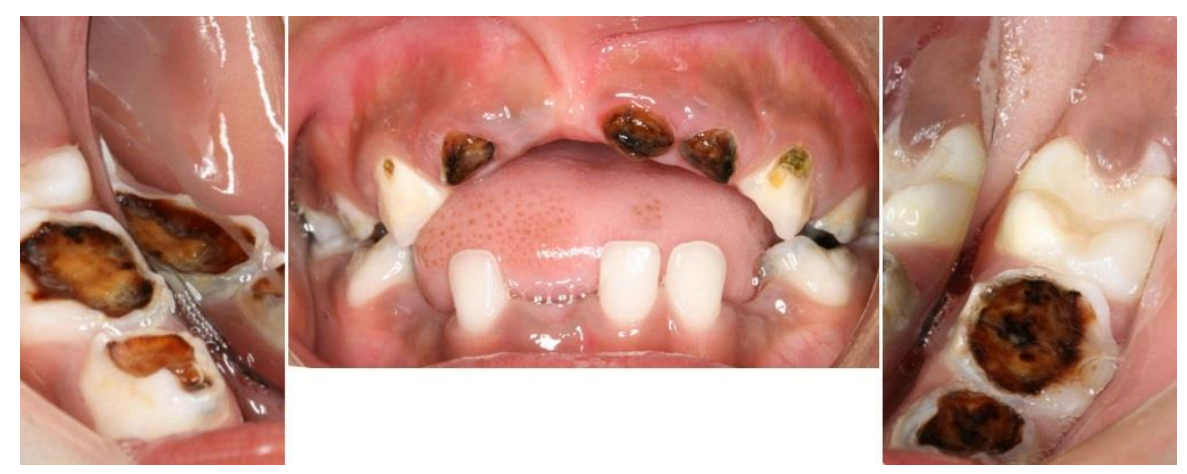

Fig. 2 Case scenario 2. A fearful and uncooperative five and a half year old boy with severe caries, but no pain

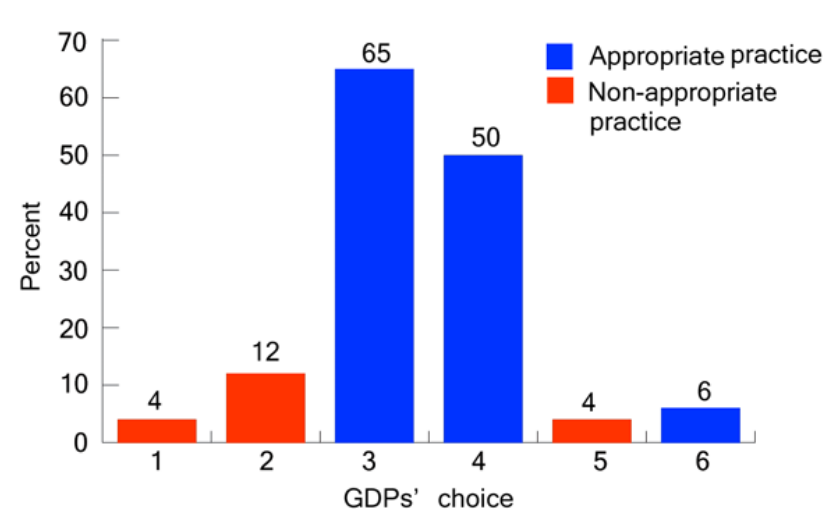

Fig. 3 Case scenario 1. Distribution of responses from 391 general dental practitioners (GDPs) which could select up to two options. The numbers 1-6 represent precoded reply options: 1 . Wait and recall in about 3-6 months. 2. Acute treatment, hold if necessary. 3. New appointment for BMT 4. New appointment with conscious sedation. 5. Prescribe antibiotics and new appointment for treatment 6. Refer for treatment under general analgesia. 
The validation of the response categories in «Appropriate practice» and «Non-appropriate practice» was based on replies by 29 paediatric dentists (PDs).

Table 1 Variables included for the GDPs and dichotomisation

\begin{tabular}{|l|l|l|}
\hline Question & Response options & Dichotomised alternatives \\
\hline & - Male & \\
1. Gender & - Female & \\
& & \\
\hline
\end{tabular}




\begin{tabular}{|c|c|c|}
\hline $\begin{array}{l}\text { 2. Region of } \\
\text { education }\end{array}$ & 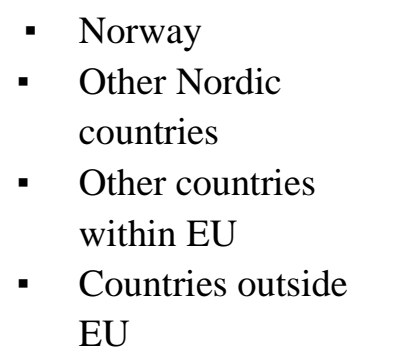 & $\begin{array}{l}\text { - } \quad \text { Nordic countries } \\
\text { - } \quad \text { Other countries } \\
\text { (EU and non EU) }\end{array}$ \\
\hline 3. Years of practice & $\begin{array}{ll}\cdot & 0-5 \\
\cdot & 6-10 \\
\cdot & 11-15 \\
\cdot & 16-20 \\
\cdot & >20\end{array}$ & $\begin{array}{l}\text {. } 0-10 \\
\text {. }>10\end{array}$ \\
\hline $\begin{array}{l}\text { 4. Proportion of treatment time } \\
\text { on children aged } 2-18 \text { years }\end{array}$ & $\begin{array}{ll}\text {. } & 0-40 \% \\
. & 41-60 \% \\
. & 61-80 \% \\
. & 81-100 \%\end{array}$ & $\begin{array}{l}\text {. } \quad 0-60 \% \\
\text {. } \quad 61-100 \%\end{array}$ \\
\hline $\begin{array}{l}\text { 5. How often do you use LA } \\
\text { when undertaking restorative } \\
\text { treatment in children aged } 3 \text { - } 5 \\
\text { years }\end{array}$ & $\begin{array}{ll}\text { - } & \text { Never } \\
\text { - } & \text { Rarely } \\
\text { - } & \text { Sometimes } \\
\text { - } & \text { Often } \\
\text { Always }\end{array}$ & $\begin{array}{l}\text { Never, rarely, } \\
\text { sometimes } \\
\text { - } \quad \text { Often, always }\end{array}$ \\
\hline $\begin{array}{l}\text { 6. How often do you find it diffi- } \\
\text { cult to do restorative treatment } \\
\text { in children aged } 3-5 \text { years? }\end{array}$ & $\begin{array}{ll}\text { - } & \text { Never } \\
\text { - } & \text { Rarely } \\
\text { - } & \text { Sometimes } \\
\text { - } & \text { Often } \\
\text { - } & \text { Always }\end{array}$ & $\begin{array}{l}\text { Never, rarely, } \\
\text { sometimes } \\
\text { - } \quad \text { Often, always }\end{array}$ \\
\hline $\begin{array}{l}\text { 7. How often do you use con- } \\
\text { scious sedation to carry out } \\
\text { treatment in patients aged } \\
\text { between } 2 \text { and } 18 \text { years? }\end{array}$ & $\begin{array}{ll}\text { - } & \text { Rarely } \\
\text { - } & 2-3 \text { times every half } \\
& \text { year } \\
\text { - } & 1-3 \text { times per month } \\
& \text { or more } \\
\text { - } & \text { At least once a week }\end{array}$ & $\begin{array}{l}\text { - } \begin{array}{l}\text { Never, rarely, 2-3 } \\
\text { times per half year }\end{array} \\
\text { - } 1-3 \text { times per } \\
\text { month or more }\end{array}$ \\
\hline
\end{tabular}

Table 2 Case scenarios and response options 


\begin{tabular}{|c|c|c|}
\hline Case & Scenario & Precoded response options \\
\hline 1 & $\begin{array}{l}\text { You receive a referral of a five-year-old } \\
\text { girl from a hygienist. The patient's record } \\
\text { states that the girl is very uncomfortable } \\
\text { and agitated, and has pain at night related } \\
\text { to caries. The child opposes clinical } \\
\text { examination, but you get a quick look and } \\
\text { take two BW radiographs. Afterwards, the } \\
\text { child resists any further contact and clings } \\
\text { to her mother. You decide that further } \\
\text { dental treatment today will be difficult, but } \\
\text { the mother wants you to carry out } \\
\text { treatment immediately (Fig. 1) }\end{array}$ & $\begin{array}{l}\text { What kind of approaches would you choose for } \\
\text { this patient? You may select one or two of the } \\
\text { most preferred treatment alternatives } \\
\text { 1. Wait until the patient is older and has } \\
\text { achieved more maturity for dental } \\
\text { treatment. Give a new appointment in } \\
\text { about 3-6 months. } \\
\text { 2. Do acute treatment the same day, } \\
\text { restraining the child if necessary. } \\
\text { Give new appointment for behaviour } \\
\text { management techniques (BMT) and then } \\
\text { treatment (within a few weeks). } \\
\text { appointment for treatment (within a few } \\
\text { weeks). } \\
\text { 6. Gefer for treatment under general } \\
\text { under conscious sedation (within a few } \\
\text { weeks). }\end{array}$ \\
\hline
\end{tabular}




\begin{tabular}{|l|l|l|}
\hline 2 & $\begin{array}{l}\text { A five and a half year old boy arrives for a } \\
\text { dental examination, accompanied by his } \\
\text { mother. He has never been to this dentist } \\
\text { before. The boy has no ailments or pain in } \\
\text { his teeth, but when he was three years old } \\
\text { extraction of teeth were done by another } \\
\text { dentist. He is now demonstrating fear and } \\
\text { uncooperative behaviour. Radiographic } \\
\text { examination was not possible due to the } \\
\text { boys' reluctance, but clinical examination } \\
\text { demonstrates no signs of fistula or } \\
\text { abscesses. The mother has no interest in } \\
\text { dental treatment for her son, as he has no } \\
\text { pain. She was told that caries is limited to } \\
\text { the primary dentition and his permanent } \\
\text { teeth are erupting (Fig. 2). }\end{array}$ & $\begin{array}{l}\text { 1. Yes } \\
\text { decisiont }\end{array}$ \\
\hline
\end{tabular}

Table 3 Dentists' (GDPs) characteristics relating to different treatment options in Case scenario 1

\begin{tabular}{|c|c|c|c|c|c|c|c|c|c|c|c|c|}
\hline \multirow{2}{*}{\multicolumn{2}{|c|}{$\begin{array}{c}\text { Treatment options } \\
\text { Case scenario } 1 \\
\text { Dentists' } \\
\text { characteristics }\end{array}$}} & \multicolumn{2}{|c|}{$\begin{array}{c}\text { "Wait } \\
\text { until } \\
\text { older, } \\
3-6 \\
\text { months" }\end{array}$} & \multicolumn{2}{|c|}{$\begin{array}{l}\text { "Acute } \\
\text { treatment } \\
\text { - hold if } \\
\text { necessary" }\end{array}$} & \multicolumn{2}{|c|}{$\begin{array}{c}\text { "New } \\
\text { appointmen } \\
\text { t for BMT" }\end{array}$} & \multicolumn{2}{|c|}{$\begin{array}{c}\text { "New } \\
\text { appointmen } \\
\text { t for } \\
\text { conscious } \\
\text { sedation" }\end{array}$} & \multicolumn{2}{|c|}{$\begin{array}{c}\text { "Prescribe } \\
\text { AB and new } \\
\text { appointment } \\
\text { ", }\end{array}$} & $\begin{array}{l}\text { "Refe } \\
\text { r for } \\
\text { GA" }\end{array}$ \\
\hline & & $\mathrm{n}$ & $\%$ & $\mathrm{n}$ & $\%$ & $n$ & $\%$ & $\mathrm{n}$ & $\%$ & $\mathrm{n}$ & $\%$ & n $\%$ \\
\hline \multirow{2}{*}{$\begin{array}{l}\text { Region } \\
\text { of } \\
\text { Educatio } \\
\mathrm{n}\end{array}$} & $\begin{array}{l}\text { Nordic } \\
\text { countrie } \\
\mathrm{s} \\
\mathrm{n}=314\end{array}$ & 12 & 3.8 & 30 & $9.6^{*}$ & 202 & 64.3 & 169 & $\begin{array}{c}53.8^{*} \\
*\end{array}$ & 12 & 3.8 & $17 \quad 5.4$ \\
\hline & $\begin{array}{l}\text { Other } \\
\text { countrie } \\
\text { s } \\
\text { (EU and } \\
\text { non EU) } \\
n=75\end{array}$ & 3 & 4.0 & 15 & $\begin{array}{c}20.0 \\
*\end{array}$ & 51 & 68.0 & 26 & $\begin{array}{c}34.7^{*} \\
*\end{array}$ & 4 & 5.3 & $\begin{array}{ll}8 & 10.7\end{array}$ \\
\hline $\begin{array}{l}\text { Years of } \\
\text { practice }\end{array}$ & $\begin{array}{l}0-10 \\
\text { years } \\
n=184\end{array}$ & 8 & 4.3 & 16 & 8.7 & 133 & $\begin{array}{c}72.3^{*} \\
*\end{array}$ & 103 & $56.0^{*}$ & 7 & 3.8 & $73.8^{*}$ \\
\hline
\end{tabular}




\begin{tabular}{|c|c|c|c|c|c|c|c|c|c|c|c|c|}
\hline & $\begin{array}{l}\text { More } \\
\text { than } 10 \\
\text { years } \\
n=207\end{array}$ & 7 & 3.4 & 29 & 14.0 & 122 & $\begin{array}{c}58.9^{*} \\
*\end{array}$ & 93 & $44.9^{*}$ & 10 & 4.8 & $188.7 *$ \\
\hline \multirow[t]{2}{*}{$\begin{array}{l}\text { Use of } \\
\text { sedation }\end{array}$} & $\begin{array}{l}\text { Never, } \\
\text { Rarely, } \\
2-3 \\
\text { times } \\
\text { every } \\
\text { half year } \\
n=266\end{array}$ & 15 & $\begin{array}{c}5.6^{*} \\
*\end{array}$ & 35 & 13.2 & 177 & 66.5 & 115 & $\begin{array}{c}43.2^{*} \\
*\end{array}$ & 13 & 4.9 & 155.6 \\
\hline & $\begin{array}{l}1-3 \\
\text { times pr. } \\
\text { month } \\
\text { or more } \\
n=125\end{array}$ & 0 & $0 * *$ & 10 & 8.0 & 76 & 62.4 & 81 & $\begin{array}{c}64.8^{*} \\
*\end{array}$ & 4 & 3.2 & 108.0 \\
\hline
\end{tabular}

$* p<0.05, * * p<0.01$

Table 4 Dentists' (GDPs) characteristics relating to different treatment options in Case scenario 2. The statement: "The dentist decides that the patient will get a new notice in about 9 months."

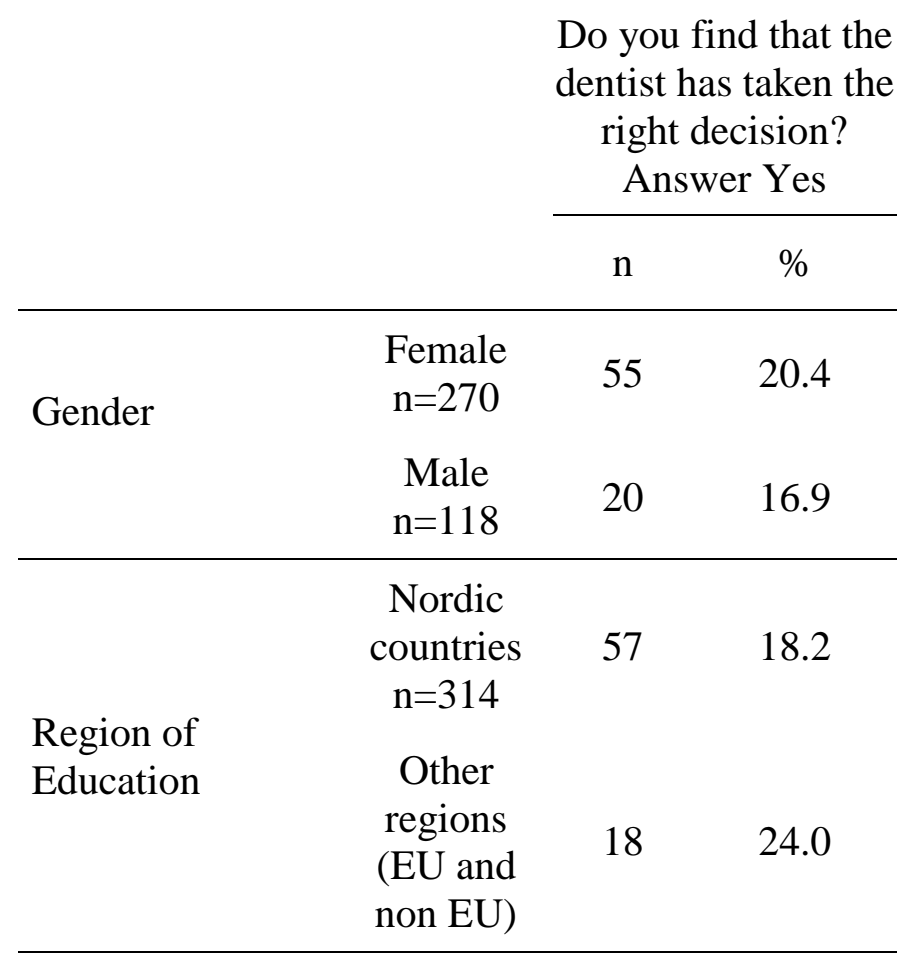




\begin{tabular}{|c|c|c|c|}
\hline \multicolumn{4}{|c|}{$\mathrm{n}=75$} \\
\hline \multirow{2}{*}{ Years of practice } & $\begin{array}{c}0-10 \text { years } \\
n=184\end{array}$ & 23 & 12.5 \\
\hline & $\begin{array}{l}\text { More than } \\
10 \text { years } \\
n=207\end{array}$ & 52 & $25.1 * *$ \\
\hline \multirow{2}{*}{$\begin{array}{l}\text { Proportion of } \\
\text { treatment time } \\
\text { working with } \\
\text { children } \\
\text { aged 2-18yr }\end{array}$} & $\begin{array}{l}0-60 \% \\
n=222\end{array}$ & 31 & 14.0 \\
\hline & $\begin{array}{c}61-100 \% \\
n=165\end{array}$ & 42 & $25.5 * *$ \\
\hline \multirow{2}{*}{$\begin{array}{l}\text { Dentists' use of } \\
\text { local anesthesia } \\
\text { in children aged } \\
3-5 \text { years }\end{array}$} & $\begin{array}{c}\text { Never, } \\
\text { Rarely } \\
\text { Sometimes } \\
\mathrm{n}=229\end{array}$ & 44 & 19.2 \\
\hline & $\begin{array}{c}\text { Often, } \\
\text { Always } \\
n=160\end{array}$ & 30 & 18.8 \\
\hline \multirow{2}{*}{$\begin{array}{l}\text { Difficulties } \\
\text { doing restorative } \\
\text { Treatment in } \\
\text { children aged 3-5 } \\
\text { years }\end{array}$} & $\begin{array}{c}\text { Never, } \\
\text { Rarely } \\
\text { Sometimes } \\
\mathrm{n}=189\end{array}$ & 35 & 18.5 \\
\hline & $\begin{array}{l}\text { Often, } \\
\text { Always } \\
n=200\end{array}$ & 39 & 19.5 \\
\hline \multirow{2}{*}{$\begin{array}{l}\text { Dentists' use of } \\
\text { sedation }\end{array}$} & $\begin{array}{c}\text { Never, } \\
\text { Rarely, 2- } \\
3 \text { times } \\
\text { every half } \\
\text { year } \\
n=266\end{array}$ & 59 & 22.2 \\
\hline & $\begin{array}{l}\text { 1-3 times } \\
\text { every } \\
\text { month or } \\
\text { more } \\
n=125\end{array}$ & 16 & $2.8^{*}$ \\
\hline
\end{tabular}

